\title{
Should We Transform? Integration Cultural Ethics And Values in Chemistry Teaching And Learning
}

\author{
Y. Rahmawati, A. Ridwan \\ Universitas Negeri Jakarta \\ Jakarta, Indonesia \\ yrahmawati@unj.ac.id
}

\begin{abstract}
The paper reveals 2-year longitudinal research study on integration cultural ethics and values in chemistry teaching and learning by integrating Culturally Responsive Teaching (CRT). Indonesia diversity in geographical, cultural practices, values, and beliefs become the challenges in implementing standards-based education system and the policy for current curricula. This paper used a qualitative research methodology. Multiple data collections were obtained through interviews, observations, and reflective journals. The participants engaged were chemistry teachers, pre-service teachers, and students of six secondary schools in Jakarta. The results showed that first, the students and the teachers engaged in critical reflection on their own values and social issues through deep chemistry learning. Second, the teachers and pre-service teachers were struggling in shifting their paradigm to transformative and empowering teaching, providing a supportive role for students, and developing students' critical reflective thinking skills and agency. Third, the students faced the challenges in shifting their paradigm and role as transformative learners. Finally, the comprehensive approaches need to develop continuously for shaping students as holistic individuals in facing global competitiveness.
\end{abstract}

Keywords-cultural ethnics; chemistry teaching and learning; transform;

\section{INTRODUCTION}

Indonesia with the diversity in geographical, cultural practices, values, and beliefs become the challenges in implementing the standards-based education system (Government Law 20/2003) and the policy for current curricula. The curricula 2013 emphasizes on ethics and values learning for developing students' character as a holistic individual, not only knowledge and skills. Currently, Indonesia students grow up with different cultures that influence the set of values and beliefs, including in their learning. The process of globalization and cross-cultural interactions among ethnic groups in Indonesia create different cultural identities. As the result, they lost their first cultural identity.

The concepts of culture have emerged from different perspectives, including anthropology, linguistics, and psychology. Within these perspectives, culture consists of behaviors, values, beliefs, knowledge, and practices that embedded through interactions to become local or traditional cultures. Drawing on these theoretical perspectives, the concept of culture used focuses on the values, beliefs, practices, and related symbols of a culture that have been shaping holistic individual in the education system. In this paper, the culture used is not only the practices but also ethics and values. The students should have the opportunity to consider ethics and values when facing the situations that lead them to make and solve the problems.

In chemistry classrooms, we can develop multicultural classrooms by embracing culturally responsive teaching and integrating it with the cultural ethics and values. Aikenhead (2000) points out students' stages of learning as a rote learning, in-depth meaning-making and learning as a cultural phenomenon. Teachers who only focus on students' achievement in order to pass the assessments and curriculum in the teaching and learning process will give a bad result in students' learning.

Gay (2000) and Ladson and Billings (1995) defines culturally responsive teaching as using the cultural knowledge, prior experiences, and performance styles of diverse students to develop intellectual, social, emotional, and political learning. The learning model Culturally Responsive Teaching by Hernandez, Morales, and Shroyer (2013) consists of five main categories of content, they are integration, facilitating of knowledge construction, prejudice reduction, social justice, and academic development. This paper portrays the opportunities and challenges of integration cultural ethics and values in chemistry instructions focusing on the foundation concepts of curricula images and transformative learning that should be integrated into teaching and learning.

\section{METHOD}

CRT has been implemented by integrating the concept of ethnochemistry in the phase of cultural understanding. The qualitative method was employed in the study with observations, interviews, reflective journals, and documents analysis as data collection. This research was conducted at 6 Secondary Schools in Jakarta, Tangerang, and Bekasi in year 10 and 11. Total participants 237 students with 6 pre-service teachers, and 6 in-service teachers.

In this study, the ethnochemistry CRT model which has been developed involves 5 main steps of-self-identification, 
cultural understanding, collaboration, critical reflective thinking, and transformative construction.

\section{RESULT AND DISCUSSION}

In this approach, the students developed their understanding of their own cultural background and differences with others (self-identification phase). In the following phase of cultural understanding, the ethnochemistry was integrated into the chemistry topics discussed in this firstyear study, say, hydrolysis, electrolyte solutions, and alcohol concepts with the stories of Roti Buaya, Jeruk Nipis, Cuka Bali, and Dewi Sri. These stories helped them to understand their culture from cultural perspectives as the basic principle of ethnochemistry. The students engaged with the collaborations with their peer in collaboration phase in which the teachers employed different teaching approaches based on students' characteristics. In addition to the basic principle of transformative research, the critical reflective thinking, and transformative constructions. The students have faced the dilemmas in solving the problems, then reflected on their values and ideas. The students realized the hegemonic culture which influenced their thinking and action (Rahmawati \& Taylor, 2015; Rahmawati \& Taylor, 2017). In addition to the researchers worked with the in-service and pre-service teachers for engaging the students in both hard and soft skills development. This study reports on students soft skills of collaboration skills, high order thinking skills, critical reflections on values and social issues and student engagement in chemistry learning.

\section{A. Students' Soft Skills and Critical Reflections on Values and Social Issues}

In five phases, the teachers implemented different cooperative teaching approach to develop students' soft skills. In this approach, the teachers facilitated students to understand the chemistry concepts and solve the problems which provide opportunities for the students to develop empathy communication, team working, and self-confidence.

"The role of teachers was excellent in facilitating learning because the teacher's role is different from our usual classroom. We usually listened to the teacher, but now we have more freedom in our learning" (Student Interview, March 3, 2016)

The students usually learn from chemistry textbook and followed the teachers' instruction. In bringing different approaches and the culture along to chemistry concepts has helped them to develop their knowledge (Rahmawati, Ridwan, and Nurbaity. It is important to assist the students in learning to be critical, independent thinkers who are opened to other ways of knowing. According to Hernandez, Morales, and Shroyer (2013), CRT can help students to become critical and reflective thinkers, understand, and represent information provided. The teacher also appreciated students' questions that lead to students' self-confidence. So, it makes the students became more confident in expressing their opinion and learning chemistry.
The students started to develop critical reflections on values and social issues during culturally responsive teaching model were implemented. The implementation of content integration with ethnochemistry has led not only to develop the cognitive value but also the cultural value and character of students. The social justice was being raised to encourage students to ask questions and/or challenge to show their status quo. The attitude of being aware of other differences was developed, especially in group discussions. According to Palmer (2007), by embracing diversity, we realize connectedness with others which are empowering for transforming our lives.

I realized, we have different opinions, ethnic background, different views which put me into a better understanding of these differences (Student Reflective Journal, 24 February 2016).

Based on the results of some students do not like chemistry because it is oriented towards the chemistry scoring test. They usually understand that the purpose of learning is for passing the exam. After implementation of culturally responsive teaching, they started new perspectives on learning chemistry. The students engaged in chemistry learning because they found it was related to their own background and everyday lives. This is consistent with the results of research Marasinghe in Papua New Guinea on ethnochemistry which influenced students engagement (Marasinghe, 2016).The students' engagement was shown both in their understanding of chemistry concepts, their learning motivation, and most strongly improved are their soft skills. Among the soft skills, the nation's culture and character education are related to graduate competencies from Curriculum 2013.

\section{B. Teachers' Challenges in Shifting Paradigms and Being Transformative Educators}

In the study, both pre-service and in-service teachers faced the challenges as they usually focused on students achievement than meaningful learning experiences. In implementing these changes, they have to transform their paradigm from the teacher as a controller to the teacher as a facilitator. They also have to shift the focus of their teaching and learning process from only on knowledge development to soft skills development. The curriculum metaphors are divided as content or subject matter, a program of planned activities, learning outcomes, cultural reproduction, experience, discrete tasks and concepts, agenda for social reconstruction. Currently, it becomes an important matter to be reflected by the teachers in the way of integrating cultural ethics and values in their instructions (Schubert, 1986; Pinar, 1975). In this study, the pre-service and in-service teachers engaged in transformative learning through the reflective process to change (Mezirow \& Taylor, 2009). Taylor's (2013) article on transformative education for science educators also has powerful guidelines for transformative teaching based on five ways of knowing to be involved in transformative learning: cultural-self knowing (self-realisation), relational knowing (opening to difference), critical knowing, visionary and ethical knowing (over the horizon thinking), knowing in action 
(making a difference). However, it was a challenge as the teachers focused on students achievements and curricula content, as stated by them.

As a pre-service teacher, conducting research in dilemma stories was really challenging. Students with cultural differences tried to solve problems within the chemistry context. I realized that it's a powerful approach to develop students' emotional intelligence within our values and beliefs (Anah, pre-service teacher, Mei 5, 2014)

I am glad to learn the new approach to teaching chemistry which I am engaged in constructing the story and related it into chemistry curricula (Heryati, Chemistry teacher, Mei 10, 2014)

They need to hold the constructivism as referent as proposed by Tobin and Tippins (1993) to apply constructivism in different situations. The teachers need to realize that the essential role is to become a mediator, in order to introduce the students to the cultural process in the learning process. The teacher's role as a mediator of learning involves two critical components: (1) monitoring students' learning and (2) providing constraints to guide the students' thinking in productive directions.

In the context of integrating cultural ethics and values, being transformative educators who employ (1) constructivism as a referent, (2) empowering teacher-student relationships, and (3) dialectical thinking (Rahmawati, 2013) could help the teachers in facing the challenges and opportunities in the standards-based education system in Indonesia. However, as the discussion above, teachers need to shift and enrich their paradigms in teaching and learning for creating meaningful and empowering learning experiences for the students.

\section{CONCLUSION}

The culturally responsive teaching with etnochemistry integration makes students aware of the role of chemistry in everyday lives, in particular in an engagement of Indonesia cultures within this globalization. This approach will be one innovative way for culture sustainability through chemistry learning. Chemistry students need to be engaged with a social problem and encourage them to argue and thinking critically with different perspectives.

\section{REFERENCES}

[1] Aikenhead, G. S. I., (pp. ). UK. 2000. Renegotiating the culture of school science. In J. L. R. Millar, \& J. Osborne (Ed.), Improving science education: The contribution of research (pp. 245-264). Birmingham, UK: Open University Press.

[2] Basseches, M. 2005. The development of dialectical thinking as an approach to integration. Integral Review 1, 47-63.

[3] Gay, G. 2000. Culturally Responsive Teaching: Theory, Research, \& Practice. New York: Teachers College Press.

[4] Government Laws. 2003. Undang-UndangRepublik Indonesia Nomor 20 Tahun 2003 about National Education System.

[5] Grundy, S. 1987. Curriculum: Product or praxis. New York: The Falmer Press.

[6] Hernandez, C. M., Amanda R. Morales dan M. G. Shroyer. 2013.The development of a model of culturally responsive science and mathematics teaching. Cultural Studies of Science Education, 8 (4), 803820 .

[7] Ladson, G. dan Billings. 1995.Toward culturally relevant pedagogy. American Educational Research Journal,32(3), 465-491.

[8] Marasinghe, B. Ethnochemistry, and ethnomedicine of ancient Papua New guineans and their use in motivating secondary school children and university undergraduates in PNG. 2016.Universal Journal of Educational Research, 4(7), p. 1724-1726.

[9] Mezirow, J., Taylor, E. D., \& Associates (Eds.). 2009. Transformative learning in practice: Insights from community, workplace, and higher education. San Fransisco: Jossey Bass, A Wiley Imprint.

[10] Palmer, P. J. 2007. The courage to teach: Exploring the inner landscape of a teacher's life. San Fransisco: Jossey-Bass, A Wiley Imprint.

[11] Pinar, W. 2004. Understanding curriculum: An introduction to study of historical and contemporary curriculum discourses (Ch. Autobiography: A revolutionary act). New York: Peter Lang.

[12] Rahmawati, Y. 2013. Revealing and reconceptualizing teach-ing identity through the landscapes of culture, religion, transformative learning, and sustainability education: A transformation journey of a science educator. Doctoral thesis, Curtin University, Australia.

[13] Rahmawati, Y., \& Taylor, P. C. 2015. Moments of critical realization and appreciation: A transformative chemistry teacher reflects. Reflective Practice: International and Multidisciplinary Perspectives, 16(1), 31-42

[14] Rahmawati, Ridwan,\& Nurbaity. 2017. Should We Learn Culture in Chemistry Classroom? Integration Ethnochemistry in Culturally Responsive Teaching. The AIP Proceeding, 4th ICRIEMS Conference, 15-16 May 2017.

[15] Rahmawati, \& Taylor. 2017. The fish becomes aware of the water in which it swims": revealing the power of culture in shaping teaching identity. Cultural Studies of Science Education, 1-13

[16] Schubert, W. H. 1986. Curriculum: Perspective, paradigm, and possibility. New York: Mcmillan Publishing Company.

[17] Taylor, P. C. 2013. Transformative research for meaning-centered professional development. In O. Kovbasyuk \& P. Blessinger (Eds.), Meaning-centred education: International perspectives and explorations in higher education. New York, NY: Routledge.

[18] Tobin, K., \& Tippins, D. 1993. Constructivism as a referent for teaching and learning. In K. Tobin (Ed.), The practice of constructivism in science education (pp. 3-21). Washington: AAAS Press. 